\title{
sciendo
}

Folia Oeconomica Stetinensia

Volume 20 (2020) Issue 1

DOI: $10.2478 /$ foli-2020-0007
WYDZIAL NAUK EKONOMICZNYCH I ZARZA¿DZANIA

\section{MODEL OF THE MARKET VALUE OF APARTMENTS INCLUDING A TIME VARIABLE AND ENERGY FEATURES OF A BUILDING*}

\author{
Iwona Foryś, Ph.D., Associate Professor \\ University of Szczecin, Economic, Finance and Management Faculty, Econometrics and Statistics Department \\ Mickiewicza 64, 71-101 Szczecin, Poland \\ e-mail: iwona.forys@usz.edu.pl \\ ORCID: 0000-0002-2294-0672
}

Ewa Putek-Szeląg, Ph.D.

University of Szczecin, Economic, Finance and Management Faculty, Econometrics and Statistics Department Mickiewicza 64, 71-101 Szczecin, Poland

e-mail: ewa.putek-szelag@usz.edu.pl

ORCID: 0000-0003-0364-615X

Beata Ziembicka, Ph.D. Eng.

Real Estate Appraisal Office

Reduty Ordona 56/1, 71-202 Szczecin, Poland

e-mail: operaty@wp.pl

ORCID: 0000-0001-5185-6624

Received 22 October 2019, Accepted 6 March 2020

\begin{abstract}
Research background: The implementation of EU directives in national legislations imposes an obligation to monitor energy efficiency in every sector of the economy, including construction. In the era of energy conservation, which results from environmental requirements, as well as from constantly increasing energy prices, the energy consumption of premises and buildings becomes an important prerequisite for decisionmaking processes in the real estate market. There have also been changes in the provisions of the Act on Real Estate Management, which impose an obligation on the professional group of property appraisers to incorporate energy performance certificates for buildings and premises into the valuation process. Energy intensity in terms of the demand for heating of multi-family residential buildings will be the basis for the assessment of its impact on the market value of residential units.
\end{abstract}

\footnotetext{
* The project is financed within the framework of the program of the Minister of Science and Higher Education under the name "Regional Excellence Initiative" in the years 2019-2022. project number 001/RID/2018/19. the amount of financing PLN 10.684.000.00.
} 
Purpose: The article analyses the energy intensity of different types of buildings (e.g. low and high-rise buildings) and the diverse distribution of units in the building, especially with regard to their exposure to the different point of the compass. The research covered the Słoneczne housing estate in Szczecin, in a situation where the property appraiser does not have access to the energy performance certificates of the estimated apartments as well as apartments taken for comparison. The aim of the study is to identify the relationship between energy intensity and market value of residential units on the selected real estate market. The analysis will be based on data from the Price and Value Register of the County Office, a collection of statistics and public information as well as on the authors' own databases and research.

Research methodology: A multidimensional analysis will be used to distinguish homogeneous groups of residential units due to their property attributes. The study will also employ a valuation model including energy intensity and time variables.

Results: The study showed that building type is one of the features determining energy consumption by a building. Depending on the period, the introduced attributes explained the evolution of the unit price at $78 \%, 75 \%$ and $24 \%$. The parameters of the variables Size, Neighborhood and Time were found to be statistically significant. What is more, in all three periods, the value of the residential unit was significantly affected by the type of building which determined the energy performance of the building.

Novelty: Energy intensity in terms of the heating demand of multi-family residential buildings will be the basis for the assessment of its impact on the market value of residential units. The article analyses the energy intensity of different types of buildings (e.g. low and high buildings) and the different location of units in a building, especially in relation to the directions of the world.

Keywords: Real estate market analysis, energy intensity, market value

JEL classification: C10, R31

\section{Introduction}

Over many years the most important attribute of a property is its location but also technical features that affect its energy performance are increasingly important for users. Rational energy management throughout the lifetime of the property determines its economic use at justified costs. The EU directives aimed at supporting the process of energy saving and the promotion of energy efficient solutions applied by the housing construction sector serve as a stimulus to take proper measures in this respect.

The primary measure implemented in the member states of the European Union with the purpose of assessing the energy performance of a building or its part (an apartment) is the energy certification of both newly built, existing and leased housing stock. In underdeveloped markets of energy performance certificates; there are other data available on the basis of which a benchmark level of energy intensity of a building or apartment can be established. Information about buildings, both regarding its technical condition and energy performance, should be collected and analyzed by property valuers. 
With the example of a selected, homogeneous housing stock located in one of the housing estates in Szczecin, an attempt was made to create a model of the market value of apartments with a time variable that includes the energy characteristics of the building. So far, the attributes of buildings that influence the energy demand for heating purposes have been ignored in the market valuation of apartments, although the binding regulations impose the necessity to ensure that the existing stock is used with the highest possible energy efficiency.

\section{Influence of market features on property market value.}

Identification of the relationship between energy intensity and property market value

For years the improvement of the quality of the natural environment, increasing energy efficiency and reducing carbon dioxide emissions have been the key issues addressed in EU directives and in national legislation (Kryk, Kaczmarczyk, 2016). The construction sector in the European Union is responsible for more than $40 \%$ of the demand for non-renewable primary energy (EP) and one third of carbon dioxide emissions. The core instrument to support these objectives and commitments include the Energy Performance of Buildings Directive (EPBD). ${ }^{1}$ The aim of the Directives is for Member States to introduce and apply harmonized calculation methods to obtain reliable information on the building and its energy class. The document in which information and guidance for improving the quality of a building are to be collected is the energy performance certificate, based on consistent assessment criteria and national legislation. The implementation of EU directives into national conditions is executed in the building law and legal regulations governing the methodology of preparing energy performance certificates. They set out the requirements for the proper insulation of external walls and energy savings.

Building regulations have not been without influence on real estate law. The Act on Real Estate Management imposes an obligation to use all necessary and available data contained, among others, in the energy performance certificate, when estimating the value of a property. The promotion of sustainable development principles, which include the energy certification of buildings, is also carried out through the European Valuation Standards (EVS, 2013, pp. 109119; EVS, 2019, pp. 161-171). It is necessary to determine in each case how much a potential buyer is willing to pay for the "green" attributes of the property in the market. The estimated value of the property is to reflect the current situation, without hypothesizing the future. Experts assess the market value on the basis of a market- and evidence-based reference parameter, such

\footnotetext{
1 Directive 2010/31/EU of the European Parliament and of the Council of 19 May 2010 on the energy performance of buildings (recast).
} 
as the energy class of a building or its parts as set out in an energy performance certificate. After analyzing the energy performance data, it is up to the valuer to assess whether they are sufficient to value the property in a comparative approach and whether the property market recognizes this attribute. Until now, when there was an insufficient number of certificates for reference properties or lack of influence of this reference feature, the valuation report included only the relevant information obtained from the energy performance certificate of the property being valued and the relevant recommendations as to beneficial improvements resulting in the reduction of energy demand. The market value should also include the potential of the building to upgrade its energy performance, e.g. as a result of renovation. Therefore, the assessment of the energy performance standard can be carried out also after the analysis of outlays and costs of the so-called "more important renovation". The "major renovation" is considered to be the fulfillment of one of the following conditions (depending on the policy pursued in a given Member State): the renovation will cover more than $25 \%$ of the surface of the external envelope, the total cost of renovation work (external envelope or technical systems) exceeds $25 \%$ of the value of the building (excluding the value of the land) (EVS, 2013, pp. 113-114, EVS, 2019, p. 166). It should be noted that the European Valuation Standards do not refer to the age of the building as a determinant of the technical condition affecting the value of the developed property, but only address the issue of the extent or costs of modernization (renovation) related to the value of the development separated from the ground (EVS, 2019, p. 166).

Tightened provisions of the directive in force in the member states are to ultimately and within a specified time horizon contribute to meeting the requirements of "zero" energy consumption by new buildings, confirmed by the result of the energy performance certificate according to the integrated efficiency standards established by each member state. However, it is the real estate market that will verify the additional "green" attributes of the real estate and their pricing weight. It is up to the valuer to monitor and carefully analyze trends and the dynamics of changes in buyer preferences (Kucharska- Stasiak, 2010, p. 12) in line with the principle that "valuations cannot anticipate and correct the market" (Konowalczuk, 2014, pp. 233-236).

It is still generally acknowledged that an energy-efficient building is one that has highly efficient installations and emits as little heat as possible into the environment. However, low energy consumption is considered to be $50 \%$ lower than in the case of traditional buildings erected in compliance with contemporary norms and standards (Ziembicka, 2019, p. 121). The energy performance of a building may depend on its geographical location, as well as on the technical parameters of the building and apartments it contains. Location is related to the climatic zone in which the building is situated, the variability of external temperature, wind speed and 
direction, solar intensity. The quality of energy performance is determined by: thermal quality of the building envelope, shape of the building, location of the apartment in the building, type of ventilation, window and door woodwork, technical equipment and building automation. Also important is the layout of rooms, adapted to the climatic conditions in the region. Therefore, the value of a building is determined by measures taken to reduce energy consumption, maintain the users' thermal comfort and well-being, while maintaining its visual value and prolonging its lifespan, as well as by ensuring regular inspections, repairs, maintenance and refurbishment of the building and its facilities (Ziembicka, 2016, pp. 198-205).

Technical measures to reduce the energy intensity of buildings can also contribute to an increase in the market value of the property. As indicated by the results of research by I. Foryś, in the case of buildings located outside the very centre of Szczecin, the process of thermal upgrading may result in a higher market value of apartments by about 15-18\% (Foryś, 2006, p. 55). However, according to the authors of this study, the location in the centre of Szczecin is still the most valuable attribute of a property, and thermal upgrading of buildings is only a bonus for buyers, thus having no impact on the market price of apartments (Putek-Szeląg, Ziembicka, 2016, pp. 409-418). The findings of a study conducted in Olsztyn by M. Bełej and P. Gulmontowicz also indicate that thermal upgrading is a feature irrelevant to the price of an apartment in a multi-family building (Bełej, Gulmontowicz, 2009, pp. 59-62).

Now, due to the large proportion of thermally upgraded buildings in the existing stock of multi-family buildings, potential buyers perceive insulated facades only in the context of improved aesthetics and, as future users, they increasingly take into consideration other possible factors that can have an effect on savings to be obtained in the long-term perspective. The analysis of real and theoretical energy demand for the central heating and ventilation of apartments in one of the multi-family housing estates in Zielona Góra has shown that the size and position of an apartment in a building determine the unit energy consumption for heating purposes. The researchers analyzed one-, two- and three-room units of end-wall and central position in 3-storey buildings of homogeneous construction located in two housing estates in the northern part of the city. After one and a half years of observation of the measurements recorded in the period 2008-2009, they found that the level of unit heating energy consumption was related to the position of the residential unit. The most economic apartments turned out to be 3-room, centrally-positioned flats on the first and second floor. The least advantageous in terms of energy intensity were two-room end-wall apartments situated on the ground floor (Alsabry, Pigalski, Maciejewski, 2010, pp. 42-43). 
Therefore, in the absence of energy performance certificates, one of the characteristics of the apartment that may be indicative of its energy performance may be its position in the building (end-wall, central) and its exposure to the sun.

The topic undertaken in the article is the next stage of research aiming at determining the impact of energy intensity on the market value of residential units (Foryś, Putek-Szeląg, Ziembicka, 2019), in which non-linear models are tested and additional variables are included, such as a time variable.

\section{Research methods}

When determining prices, the researchers used classical econometric models, most frequently the linear regression of many variables. There are two groups of nonlinear models: those that can be reduced to linear models after appropriate transformation, and nontransformable nonlinear models that cannot be converted to linear models (Coulson, Dong, Sing, 2018). In each valuation model it is necessary to determine the features describing the tested object. Therefore, in the first stage of the study, variables that significantly affected the value of the property were specified.

The Spearman rank correlation coefficient was calculated as follows (Kendall, 1948, p. 29):

$$
\rho_{x y}=\rho_{y x}=\frac{\frac{1}{6}\left(n^{3}-n\right)-\left(\sum_{i=1}^{n} d_{i}^{2}\right)-T_{x}-T_{y}}{\sqrt{\left(\frac{1}{6}\left(n^{3}-n\right)-2 T_{X}\right)\left(\frac{1}{6}\left(n^{3}-n\right)-2 T_{Y}\right)}}
$$

where $d_{i}=\operatorname{rank} x_{i}-\operatorname{rank} y_{i}$

$$
\begin{aligned}
& T_{x}=\frac{1}{12} \sum_{j}\left(t_{j}^{3}-t_{j}\right) \\
& T_{y}=\frac{1}{12} \sum_{k}\left(u_{k}^{3}-u_{k}\right)
\end{aligned}
$$

$t_{j}$ - number of observations in a sample containing objects with the same $j$-th rank value of the characteristics $x$,

$u_{k}$ - number of observations in a sample containing objects with the same $k$-th rank value of the characteristics $y$,

$n$ - number of observations. 
Then, for the obtained set of variables and randomly selected cooperative residential units, the transactions were valued using linear regression.

Linear models, which in the form of structural parameters determine the force of direct interactions of an exogenous variable with an endogenous variable, are commonly used thanks to the simplicity of their interpretation (Bailey, Muth, Nurse, 1963). The authors used the forward stepwise regression, where the procedures consist in adding in subsequent versions of the model the variables that are most strongly correlated with the explained variable (Grabiński, Wydymus, Zeliaś, 1982). The significance of parameters and the significance of the determination coefficient were assessed (Putek- Szeląg, 2004).

The applied linear model of multiple regression with a time variable can be written:

$$
Y_{t}=\alpha_{0}+\alpha_{0}^{*} U_{t}+\alpha_{1} X_{1 t}+\ldots+\alpha_{k} X_{k t}+\xi_{t}
$$

where:

$Y_{t}$ - dependent variable over time, unit transaction prices of properties,

$X_{t}$ - independent variables over time, attributes of properties,

$\alpha_{k}$ - parameters of the independent variable,

$U_{t}$ - function of time (dychotomous),

$t$ - time variable,

$\xi_{t}-$ error term.

The authors also used an exploratory factor analysis, which aimed at classifying objects in spaces defined by new variables - factors and their division. Factor analysis is used to reduce the number of variables and to detect the structure of the relationships between them. Multidimensional analyses are increasingly popular methods of examining phenomena occurring in the real estate market (Foryś, 2013) because they allow for the simultaneous measurement of the phenomena occurring in this market which, due to its specificity, usually cannot be described by one or two variables.

The authors of the main concept of a factor analysis are psychologists Ch. Spearman (1904) and L.L. Thurstone (1913). The former introduced the concept of a single general factor to explain the results of intelligence tests; the latter created the theoretical basis for a factor analysis (Colley, Lohnes, 1971). Variables accepted for analysis should be correlated so that the common factor is easy to interpret, which means that it is necessary to examine the significance of the relationships between variables. The validity of a factorial analysis is assessed using the Bartlett sphericity test. It verifies the null hypothesis that the correlation matrix is the unit 
matrix (all correlation coefficients are equal to zero), and the alternative hypothesis that the correlation matrix is different from the unit matrix. The null hypothesis is checked by the chi square statistics with degrees of freedom at $p(p-1) / 2$. The adequacy of the correlation matrix is assessed by the KMO (Kaiser-Mayer-Olkin) test, which, when closer to unity, provides a stronger basis for the use of a factor analysis. The authors used a factor analysis to group the states of the attribute Type of Building into a smaller number of variants, and then confirmed the correctness of classification with a discriminatory analysis.

\section{Results}

The analysis covers data from the Housing Cooperative "Dąb", a collection of public statistics and information, databases and own research of the authors. The scope of the research embraces selected buildings from the housing stock of the Housing Cooperative built in large plate technology (mainly in the Szczecin system) between 1979 and 1984. The authors also examine data concerning readings of energy consumption units and transaction data from the secondary market of residential units in the above mentioned buildings in the years 2004-2017. The database includes 1028 transactions.

The study focused on the housing stock situated in the following streets: Jasna, KostkiNapierskiego, Rydla, Łubinowa and Lniana.

In the study the following attribute variants are coded as follows:

1. Building type

2. Neighborhood: good -1 , bad -0

3. Access to public transport: close -1 ; remote -0

4. Position on storey: central - 1; end-wall - 0

5. Size: small -2 ; medium -1 ; large -0

6. Technical condition of building: $\operatorname{good}-1$; bad -0

7. Sun exposure: best -2 ; average -1 ; worst -0

8 . Heating energy unit consumption: lowest -0 , average -1 , high -2 , very high -3

9. Position in building: better -0 ; worse -1 .

Features affecting the energy intensity of buildings and apartments have been added intuitively and are based on the professional experience of the authors (Table 1). 
Table 1. Attribute list and two variants of characteristics

\begin{tabular}{|c|c|c|c|c|}
\hline No & Characteristics & $\begin{array}{c}\text { Characteristic } \\
\text { attribute }\end{array}$ & $\begin{array}{c}\text { Attribute } \\
\text { variant coding }\end{array}$ & Description \\
\hline \multirow{2}{*}{1} & \multirow{2}{*}{ Neighborhood } & good & 1 & vicinity of schools and shops \\
\hline & & bad & 0 & far from schools and shops \\
\hline \multirow{3}{*}{2} & \multirow{3}{*}{$\begin{array}{l}\text { Access to public } \\
\text { transport }\end{array}$} & close & 0 & $\begin{array}{l}\text { housing estate periphery between Jasna } \\
\text { and Łubinowa streets }\end{array}$ \\
\hline & & \multirow{2}{*}{ remote } & \multirow{2}{*}{1} & housing estate center along \\
\hline & & & & Rydla and K. Napierskiego streets \\
\hline \multirow{2}{*}{3} & \multirow{2}{*}{$\begin{array}{l}\text { Apartment position } \\
\text { on storey }\end{array}$} & end-wall & 0 & ground level, top storey \\
\hline & & central & 1 & other storeys in between \\
\hline \multirow{5}{*}{4} & \multirow{5}{*}{$\begin{array}{l}\text { Floor area/number } \\
\text { of rooms }\end{array}$} & small & 2 & M-2: $27.1-33.10 \mathrm{~m}^{2}$ \\
\hline & & \multirow{2}{*}{ medium } & \multirow{2}{*}{1} & M-3: $44.4-49.00 \mathrm{~m}^{2}$ \\
\hline & & & & M-4: $53.4-59.70 \mathrm{~m}^{2}$ \\
\hline & & \multirow{2}{*}{ large } & \multirow{2}{*}{0} & M-5: 63.6-77.10 $\mathrm{m}^{2}$ \\
\hline & & & & M-6: $84.3-86.30 \mathrm{~m}^{2}$ \\
\hline \multirow{3}{*}{5} & \multirow{3}{*}{$\begin{array}{l}\text { Technical condition } \\
\text { of building }\end{array}$} & \multirow{2}{*}{ good } & \multirow{2}{*}{1} & insulated building \\
\hline & & & & or in the process of thermal upgrading \\
\hline & & bad & 0 & non-insulated building \\
\hline \multirow{7}{*}{6} & \multirow{7}{*}{$\begin{array}{l}\text { Apartment (living } \\
\text { room) sun exposure }\end{array}$} & \multirow{3}{*}{ best } & \multirow{3}{*}{2} & facing east \\
\hline & & & & facing south-east \\
\hline & & & & facing north-west \\
\hline & & \multirow{3}{*}{ average } & \multirow{3}{*}{1} & facing south \\
\hline & & & & facing south-west \\
\hline & & & & facing west \\
\hline & & worst & 0 & facing north or north east \\
\hline \multirow{4}{*}{7} & \multirow{4}{*}{$\begin{array}{l}\text { Heating energy unit } \\
\text { consumption }\end{array}$} & lowest & 0 & reading unit $/ \mathrm{m}^{2} \mathrm{P}_{\mathrm{uzz} . \mathrm{j}}$ \\
\hline & & average & 1 & reading unit $/ \mathrm{m}^{2} \mathrm{P}_{\mathrm{uzz.j}}$ \\
\hline & & high & 2 & reading unit $/ \mathrm{m}^{2} \mathrm{P}_{u z ̇ . j}$ \\
\hline & & very high & 3 & reading unit $/ \mathrm{m}^{2} \mathrm{P}_{u \dot{z} . j}$ \\
\hline \multirow{2}{*}{8} & \multirow{2}{*}{$\begin{array}{l}\text { Apartment position } \\
\text { in building }\end{array}$} & better & 0 & centrally situated - not contiguous to end-wall \\
\hline & & worse & 1 & contiguous to end wall \\
\hline
\end{tabular}

Source: own study. 
Table 2. Correlation coefficients between individual qualitative attributes of apartments

\begin{tabular}{|c|c|c|c|c|c|c|c|c|}
\hline Variables & $\begin{array}{l}\overrightarrow{0} \\
0 \\
\frac{0}{0} \\
0 \\
\frac{0}{00} \\
\overline{0} \\
\end{array}$ & 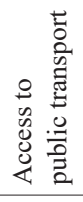 & 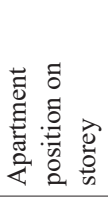 & $\stackrel{\mathbb{N}}{n}$ & 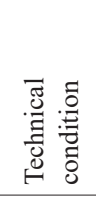 & 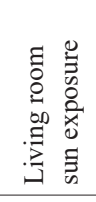 & 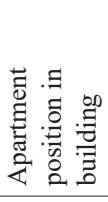 & 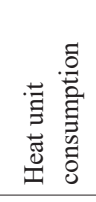 \\
\hline Neighborhood & 1.000 & 0.445 & 0.058 & -0.134 & -0.040 & -0.122 & -0.069 & 0.030 \\
\hline Access to public transport & & 1.000 & 0.011 & -0.266 & -0.055 & 0.078 & -0.080 & 0.119 \\
\hline Apartment position on storey & & & 1.000 & 0.072 & 0.052 & -0.042 & -0.027 & -0.046 \\
\hline Size & & & & 1.000 & 0.089 & -0.183 & 0.272 & -0.109 \\
\hline Technical condition & & & & & 1.000 & 0.022 & -0.007 & -0.032 \\
\hline Living room sun exposure & & & & & & 1.000 & 0.211 & 0.035 \\
\hline Apartment position in building & & & & & & & 1.000 & -0.048 \\
\hline Heat unit consumption & & & & & & & & 1.000 \\
\hline
\end{tabular}

Source: own study.

Bartlet's test (chi square $=684.46$ at 36 degrees of freedom, $\mathrm{p}=0.0000$ ) as well as the KMO criterion ( 0.5 factor value) for object grouping indicate the robustness of the factor analysis. Hence the original (intuitive) division of buildings into eight geometrical forms:

- low $\mid$ arch $\mid 11$ stairways,

- low $|\operatorname{arch}| 15$ stairways,

- low | arch | 19 stairways,

- low $|\operatorname{arch}| 23$ stairways,

- high-rise $\mid 2$ stairways | rectangular base,

- high-rise| 3 stairways | rectangular base,

- high-rise 6 stairways |cascade going down every two stairways,

- high-rise $\mid 2$ stairways | star-shaped,

was modified. The earlier results showed that the previous classification was too fragmented, which resulted in the small size of individual groups, and were eventually found useful in the analysis of heat consumption (Foryś et al., 2019). With the help of the factor analysis, buildings were consequently grouped into 5 subgroups.

Consequently (Figure 1) the authors propose to classify the buildings into five groups: Group 1 - high-rise; 3 stairways; rectangular base; Group 2 - high-rise; 2 stairways; rectangular base; star-shaped; Group 3 - low; arch; 11 stairways; 15 stairways; Group 4 - low; arch; 19 stairways; 23 stairways; Group 5 - high-rise; 6 stairways; cascade going down every two stairways. 


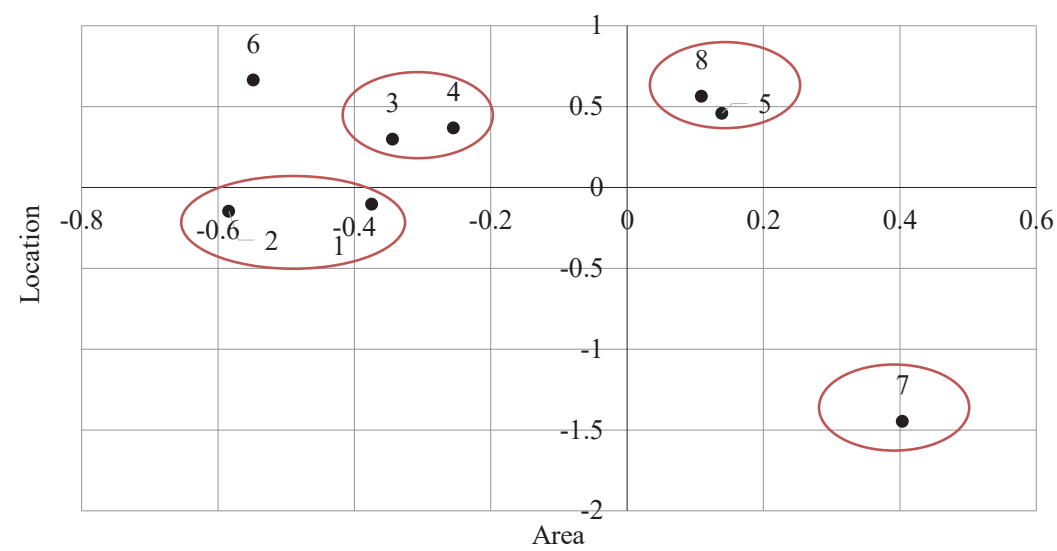

Figure 1. Chart of factor loadings

Source: own study.

On the basis of this figure, the properties were divided into 5 groups. The correctness of the indicated classification is also confirmed by the discriminatory analysis with the variable aggregating the types of buildings into five groups (Table 3 ).

Table 3. Results of the discriminatory analysis of the characteristics of buildings and residential units

\begin{tabular}{|c|c|c|c|c|c|c|}
\hline \multirow[t]{2}{*}{$\mathrm{N}=1028$} & \multicolumn{6}{|c|}{$\begin{array}{l}\text { Summary of the discriminative function analysis } \\
\text { Variables in model: 9; grouping variable: buildings group (5 group) } \\
\text { Wilk's Lambda: } 0.08917, \mathrm{~F}(36.3805)=95.771, \mathrm{p}<0.0000\end{array}$} \\
\hline & Lambda & Partial & F remvd & $\mathrm{p}$ & Toler. & 1-Toler. \\
\hline Neighborhood & 0.104482 & 0.853485 & 43.561 & 0.000000 & 0.996402 & 0.003598 \\
\hline Access to public transport & 0.465297 & 0.191649 & $1,070.285$ & 0.000000 & 0.829176 & 0.170824 \\
\hline Apartment position on storey & 0.090320 & 0.987307 & 3.262 & 0.011383 & 0.977461 & 0.022539 \\
\hline Size (1- medium, 2- small) & 0.107332 & 0.830823 & 51.670 & 0.000000 & 0.803815 & 0.196185 \\
\hline Technical condition & 0.090429 & 0.986115 & 3.573 & 0.006665 & 0.981871 & 0.018129 \\
\hline $\begin{array}{l}\text { Living room sun exposure }(2-\text { best; } \\
\text { average }-1 \text {; worst }-0)\end{array}$ & 0.111693 & 0.798384 & 64.080 & 0.000000 & 0.775202 & 0.224798 \\
\hline Apartment position in building & 0.093202 & 0.956782 & 11.462 & 0.000000 & 0.854814 & 0.145186 \\
\hline
\end{tabular}

Source: own study.

The greatest contribution to discrimination is made by the variable Technical Condition of the Building and the Apartment Position in Building, which means that they are the main variables allowing different types of buildings to be discriminated. 
In order to determine which attributes significantly affect the value of a property (unit price of an apartment), in the first stage the Spearman correlation coefficients were used. The values of these coefficients are presented in the table below (Table 4).

Table 4. Spearman coefficients of correlation between apartment unit price (PLN/m²) and individual attributes of apartments

\begin{tabular}{|c|c|c|c|c|c|c|c|c|c|c|}
\hline Variables & 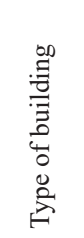 & 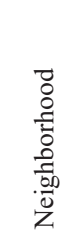 & 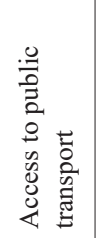 & 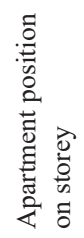 & $\stackrel{\tilde{N}}{\sim}$ & 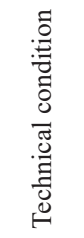 & 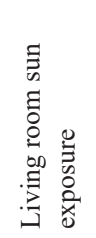 & 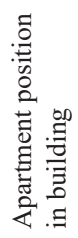 & 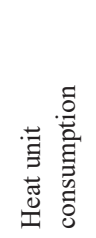 & $\stackrel{\mathscr{\Xi}}{\stackrel{G}{E}}$ \\
\hline Spearman coefficient & 0.111 & 0.022 & -0.067 & 0.080 & 0.286 & 0.161 & -0.044 & 0.152 & -0.023 & 0.505 \\
\hline Partial Spearman coefficient & 0.103 & 0.099 & 0.064 & 0.022 & 0.251 & 0.094 & -0.027 & 0.073 & 0.014 & 0.505 \\
\hline
\end{tabular}

Source: own study.

Table 4 shows the Spearman's coefficient and the Spearman's partial coefficient. Spearman's partial coefficients represent the real dependencies between individual attributes and the value of the property. This relationship is not affected by other factors. The analysis shows that the value of a property is significantly influenced by time, size, building type, neighborhood, technical condition and communication accessibility.

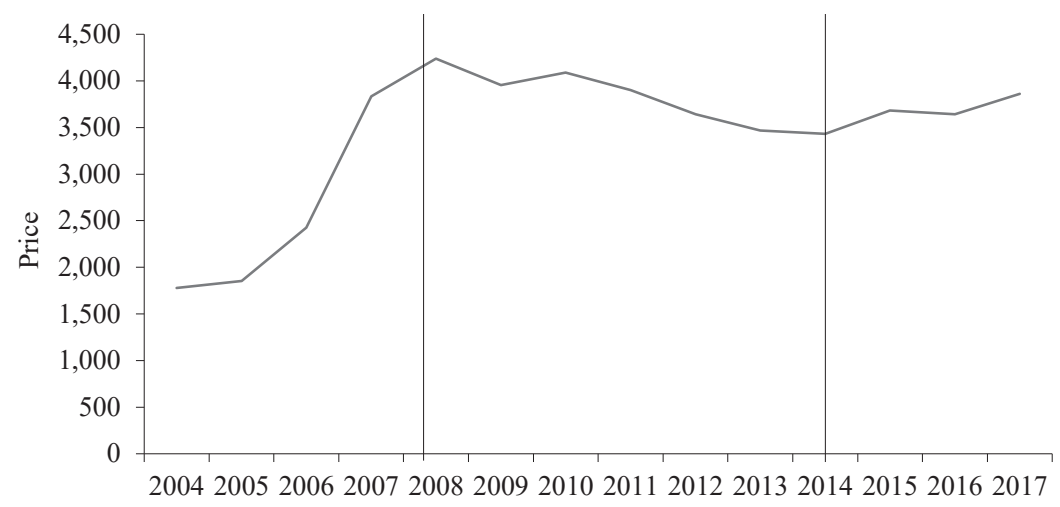

Figure 2. Dynamics of average unit price of an apartment $\left(\mathrm{PLN} / \mathrm{m}^{2}\right)$ in the analyzed part of Szczecin in the years 2004-2017

Source: own study. 
Due to the change in the unit price trend of residential units over time, the analyzed period is divided into three monotonous sub-periods. The first one covers four years between 2004 and 2008; the second one - between 2009 and 2013 and the last one starts from 2014 and ends in 2017. The parameters of the regression model are estimated accordingly. The results are presented in the table below (Table 5).

Table 5. Structural parameters of regression models in three periods of time

\begin{tabular}{|l|c|c|c|}
\hline \multicolumn{1}{|c|}{ Model parameters } & Period I & Period II & Period III \\
\hline $\mathrm{R}^{2}$ & 0.78 & 0.75 & 0.24 \\
\hline Standard deviation & 511.29 & 546.43 & 2170.67 \\
\hline Intercept parameter & 897.92 & 33.55 & 466.46 \\
\hline Standard deviation & 124.78 & 133.30 & 79.15 \\
\hline $\mathrm{t}$ & - & 676.92 & 35.33 \\
\hline Standard deviation & - & 19.99 & - \\
\hline $\mathrm{t}^{2}$ & 110.24 & - & - \\
\hline Standard deviation & 2.98 & - & 231.14 \\
\hline Size (m ${ }^{2}$ ) & 233.71 & 256.93 & 48.25 \\
\hline Standard deviation & 41.97 & 43.08 & - \\
\hline Neighborhood & 214.09 & 265.08 & - \\
\hline Standard deviation & 78.53 & 83.78 & 107.23 \\
\hline Type of building & 53.02 & 22.90 & 22.41 \\
\hline Standard deviation & 21.71 & & \\
\hline
\end{tabular}

Source: own study.

Table 5 presents the parameters of the multiple regression function taking into account the important attributes influencing the value of the property. The introduction of the time variable t significantly improved the quality of model matching (Foryś et al., 2019). Depending on the period, the introduced attributes explained the evolution of the unit price in $78 \%, 75 \%$ and $24 \%$. The parameters of the variables Size, Neighborhood and Time were found to be statistically significant. What is more, in all three periods, the value of the residential unit was significantly affected by the type of building which determined the energy performance of the building. A poor model fit in the third period results from a short period of analysis lasting three years only. In order to fully verify this relationship, the research should be continued in the future. 


\section{Conclusions}

Although the Polish construction industry is undergoing significant changes concerning the design, technology and operation in order to build as many houses with low energy needs as possible, many potential buyers do not yet perceive the energy performance certificate as an attribute that contributes to property value (Dydenko, 2014, pp. 8-17). As highlighted by I. Foryś, the current direction of changes taking place on the real estate market is clearly visible. These changes, combined with sustainable development, are aimed at ensuring better housing conditions (Foryś, 2013, p. 76). This trend is also increasingly reflected in the perception of apartment prices by real estate market participants who have started acknowledging energy and related operating costs and, as a result, are more willing to pay a higher price for their apartments.

This direction of changes on the Polish and world real estate market triggers discussions on the need for a new set of pricing features that should be included in the property valuation. The study showed that the building type is one of the features that determine energy consumption by a building. For this reason, the indirect incorporation into the valuation report of the energy intensity of a building depending on its shape (volume, geometry) is the first step in the search for simple methods that do not require studying complicated and often unavailable energy performance certificates.

\section{References}

Alsabry, A., Pigalski, W., Maciejewski, T. (2010). Teoretyczne a rzeczywiste zapotrzebowanie energetyczne na centralne ogrzewanie i wentylację mieszkań w budownictwie wielorodzinnym. Przegląd Budowlany, 11.

Bełej, M., Gulmontowicz, P. (2009). Analiza wpływu prac termomodernizacyjnych na wartość rynkową lokali mieszkalnych w zasobach wielorodzinnych. Acta Scientiarum Polonorum, Administratio Locorum, 8 (3).

Dydenko, J. (2014). Budynki energooszczędne. Rzeczoznawca Majątkowy, 4 (109).

Directive 2010/31/EU of the European Parliament and of the Council of 19 May 2010 on the energy performance of buildings. 
Directive 2012/27/EU of the European Parliament and of the Council of 25 October 2012 on energy efficiency, amending Directives 2009/125/EC and 2010/30/EU and repealing Directives 2004/8/EC and 2006/32/EC, Article 2 (4).

Europejskie Standardy Wyceny 2012 (2013). Warszawa: Polska Federacja Stowarzyszeń Rzeczoznawców Majątkowych.

Europejskie Standardy Wyceny 2016 (2019). Warszawa: Polska Federacja Stowarzyszeń Rzeczoznawców Majątkowych.

Foryś, I. (2006). Opłacalność procesów termomodernizacyjnych na przykładzie spółdzielczych zasobów mieszkaniowych. Studia i Materiały Towarzystwa Naukowego Nieruchomości, 14 (1).

Foryś, I. (2013). Społeczno-gospodarcze determinanty rozwoju rynku mieszkaniowego w Polsce. Szczecin: Wydawnictwo Naukowe Uniwersytetu Szczecińskiego.

Foryś, I., Putek-Szeląg, E., Ziembicka, B. (2019). An attempt to determine the impact of energy intensity on the market value of residential premises on the example of selected multi-family buildings. "Real Estate Management and Valuation". Reviewed manuscript approved for publication.

Kryk, B., Kaczmarczyk, J. (2016). Rachunek efektywności ekonomiczno-ekologicznej inwestycji termomodernizacyjnych spółdzielni mieszkaniowych województwa zachodniopomorskiego. Ekonomia i Środowisko, 3 (58).

Konowalczuk, J. (2014). Wycena nieruchomości do celów kredytowych. Warszawa: POLTEXT.

Kucharska-Stasiak, E. (2010). Odwzorowanie cech nieruchomości w cenach i skutki dla procesu wyceny. Studia i Materiały Towarzystwa Naukowego Nieruchomości, 18 (3).

Putek-Szeląg, E., Ziembicka, B. (2016). Analiza wpływu przeprowadzenia termomodernizacji na cenę lokali mieszkalnych na przykładzie budynku z wielkiej płyty na szczecińskim rynku nieruchomości. Studia i Prace WNEiZ US, 45 (1).

Rozporządzenie Ministra Infrastruktury i Rozwoju z dnia 27 lutego 2015 r. w sprawie wyznaczania charakterystyki energetycznej budynku lub części budynku oraz świadectw charakterystyki energetycznej (Dz.U. 2015, poz. 376 ze zm.).

Rozporządzenie Ministra Infrastruktury i Rozwoju z dnia 27 lutego 2015 r. w sprawie wyznaczania charakterystyki energetycznej budynku lub części budynku oraz świadectw charakterystyki energetycznej (Dz.U. 2015, poz. 376 ze zm.).

Ustawa 1997 z dnia 21 sierpnia 1997 r. o gospodarce nieruchomościami (t.j. Dz.U. 2018, poz. 121 ze zm.).

Ustawa z dnia 7 lipca 1994 r. prawo budowlane (t.j. Dz.U. 1994, nr 89, poz. 414 ze zm.).

Ziembicka, B. (2016). The influence of the technical condition of a building on the property's market value. Folia Oeconomica Stetinensia, 16 (1). 
Ziembicka, B. (2019). Szacowanie wartości nieruchomości z uwzględnieniem efektywności energetycznej budynku. Doctoral dissertation. Szczecin: University of Szczecin. 